\title{
Refleksiivisyystaidot ja sukupuoli ohjaavassa koulutuksessa
}

\author{
$\underline{y}$ \\ "Elämme yhä vuorovaikutuksellisemmassa ja kommunikatiivisemmassa \\ maailmassa. Sekä miehiltä että naisilta vaaditaan yhä parempia \\ refleksiivisyystaitoja ja kykyä elämänsä reflektointiin osana \\ koulutuksessa tapahtuvaa vuorovaikututusta", kirjoittaa Piia \\ Silvennoinen, joka tarkastelee artikkelissaan sukupuolten \\ refleksiivisyystaitojen eroavuuksia ohjaavassa koulutuksessa.
}

USEAT TUTKimukSET (mm. Julkunen 2003; Kortteinen 1992; Lupton 1998; Ronkainen 1999) tuovat esille sen, että myöhäismodernissa yhteiskunnassa vaadittu reflektiivinen vuorovaikutus on helpompaa naisille kuin miehille. Raija Julkunen (2003) toteaa ikätutkimuksessaan, että miesten kyvykkyys reflektoida elämäänsä on sidoksissa ammattiin ja koulutukseen. Ainoastaan analysoinnin ja kirjoittamisen ammattilainen, tohtoriksi väitellyt mies oli Julkusen tutkimuksessa valmis ja kykenevä reflektoimaan elämäänsä refleksiivisyyskulttuurin vaatimalla feminiinisellä avoimuudella. Reflektiivisyys tarkoittaa tässä yhteydessä yksilön kykyä pohdiskella omaa elämäänsä ja olla dialogisessa vuorovaikutuksessa muiden kanssa. Refleksiivisyys taas viittaa yhteiskunnan koko toiminnan muuttumiseen enemmän yksilöön itseensä viittaavaksi ja siihen, että reflektiivinen vuorovaikutus on lisääntynyt kaikilla elämänalueilla. Käsitteet kuvaavat yhteiskunnan muutosta sekä mikro- että makrotasolla.
Suvi Ronkaisen (1999) mukaan naisten parempi kyky reflektiiviseen vuorovaikutukseen on seurasta historian saatossa kehittyneestä työnjaollisesta joustavuudesta, joka on mahdollistanut naisten hakeutumisen miesten töihin. Miehille vastaavanlainen siirtymä ole onnistunut. Naisille työnjaossa avautuneet mahdollisuudet ovat rakentaneet sellaista subjektiviteettia, jolle on ominaista moniselitteisyyden sietokyky ja perspektiivien vaihto. Naisten puhe on tunnepuhetta. Naiset puhuvat omasta tilanteestaan persoonallisina kokijoina ja rönsyilevästi. Miesten puhe puolestaan on niukkasanaista asiantuntijapuhetta. Miehet välttävät puheessaan emotionaalista ja ei-faktuaalista tietoutta. (Emt.) Raija Julkunen(2003) puhuu naistapaisesta käyttäytymisestä ja Matti Kortteinen (1992) mykistä miehistä ja pohdiskelevista naisista. Kyselevä ja itseään pohdiskeleva subjekti on useammin keskiluokkainen nainen kuin mies (Julkunen 2003, 57-58). 
Kyse on myös miesten ja naisten itsensä esittämisen ja jäsentämisen eroista. Naiset esittävät itseään tuottamalla puhetta yksityisestä elämänpiiristä, esimerkiksi kodista ja siihen liittyvistä asioista. He jäsentävät elämäänsä yksityisen ja henkilökohtaisen elämään liittyvän tematiikan kautta. Miehet taas esittävät itseään puhumalla asioistaan julkiseen ja viralliseen sfärïn liittyvien seikkojen kautta. Esimerkiksi saavutukset julkisen elämän alueella kuuluvat miehille ominaiseen puhetapaan. (Hyvärinen ym. 1998, 9-10, 15-19.)

Deborah Luptonin (1998) mukaan mies- ja naistapainen käyttäytyminen määrittyvät hyvin pitkälti sukupuolittuneiden tunneilmaisujen mukaan. Miehet kontrolloivat tunteitaan naisia paremmin - sukupuoliroolien ja sosialisaation

"ERILAISET K ̈̈SITYKSET NAISEUDESTA JA MIEHEYDEST $\ddot{A}$

\section{TUOTTAVAT ESIMERKIKSI}

VUOROVAIKUTUS-

\section{TILANTEISSA MONENLAISIA} PERFORMATIIVISIA TYYLEJ ̈̈." puolisuutta, naiseutta emmekä naisellisuutta keskittämällä huomiomme joillekin tietyille elämänalueille, esimerkiksi suvunjatkamiseen, rakkauselämään tai työnjakoon. Sen sijaan on tutkittava käyttäytymisen ja toiminnan jatkumoa yrittäen ymmärtää sen moninaisuutta. Näin toimintaa ja tekemistä luonnehtivat adverbit "naisellisesti" ja "miehisesti" osoittautuvat vähemmän harhaanjohtaviksi sukupuolen kuvaamisessa kuin yleisnimet "nainen" ja "mies", jotka johtavat helposti ajattelemaan olioiden pysyviä rakenteita. Kyse on siis siitä, miten olemme, ei siitä mitä olemme. Toisin sanoen tyylin käsite auttaa paremmin ymmärtämään sukupuolijaon luonnetta, sitä että kyse ei ole vain elimistä ja ruumiintoiminnoista vaan esineistä, tiloista, kielestä ja ajatuksista.

Käsittäessämme sukupuoli-identiteetin tyylin identiteetiksi naiseus ja mieheys näyttäytyvät avoimena ja vaihtelevana. Voimme puhua esimerkiksi "naisista" ilman, että oletamme olion tai ominaisuuden, jonka kaikki "naiset" jakavat. Sukupuoli tyylinä antaa mahdollisuuden kuvata moninaisia olemisen tapoja ja sekoittaa teemoja kummastakin, naisellisen ja miehisen olemisen tyyleistä. (Heinämaa 1996, 132-163.) Näin tulkittuna avautuvat myös omassa tutkimuksessani esille tulevat naistapaisuuden ja miestapaisuuden tulkinnat suhteellisina ja monien tekijöiden summana (esimerkiksi sukupuoli, ikä, sukupolvi, luokka-asema, koulutus ja ammatti ). Erilaiset käsitykset naiseudesta ja mieheydestä tuottavat 
esimerkiksi vuorovaikutustilanteissa monenlaisia performatiivisia tyylejä, jotka omassa tutkimuksessani ilmenevät pitkälti perinteisten sukupuoliroolien mukaisina.

\section{MENETELMÄT JA AINEISTON ANALYYSI}

Tämän artikkelin pohjana olevassa tutkimuksessa (Silvennoinen 2007) tarkastelin ohjaavan koulutuksen ESR-projektin merkitystä ikääntyvien pitkäaikaistyöttömien elämässä. Toimin projektissa ohjaavana kouluttajana vuosina 1997-1999. Nykyiseen koulutuspääomaan, yhtenä kulttuurisen pääoman alalajina (ks. Liljander 1999, 111), kuuluu kyky itsereflektioon. Itsereflektiotaitojen omaksuminen on kuitenkin vahvasti yhteydessä yksilön ikään, sukupolveen, luokka-asemaan, koulutustaustaan, ammattiin ja sukupuoleen. Keskeinen tutkimustulos onkin se, etteivät haastattelemani ikääntyvät pitkäaikaistyöttömät kokeneet refleksiivisyytaitojen omaksumista koulutuksessa itselleen luontevana.

Haastattelin tutkimusta varten kahtatoista yli 45-vuotiasta pitkäaikaistyötöntä (viittä miestä ja seitsemää naista). Hain vastausta kolmeen kysymykseen, jotka koskivat ohjaavan koulutuksen merkitystä pitkäaikaistyöttömälle, iän merkitystä suhteessa koulutukseen, oppimiseen ja tulevaisuuteen sekä elämän tarinallisuutta.

Aineiston analyysi perustui tematisointiin ja tyypittelyyn. Haastatteluissa esille nousseiden viiden teeman (ohjauksen ja ohjaavan koulutuksen merkitys, koulutuksen monet merkitykset, ikääntyvä pitkäaikaistyötön, ikäkokemukset ja -käsitykset sekä työssäoppimisjakso ja tukityöllistäminen) avulla pyrin jäsentämään haastateltavien kokemusta ohjaavan koulutuksen projektista. Yhdenmukaisuuksien pohjalta (tutkimusteemat) yhdistelin haastattelut ja loin niistä viisi tyyppitarinaa, miehistä kaksi ja naisista kolme. Käytin haastatteluaineistojen tulkintojen apuna myös muita projektin aikana tuotettuja materiaaleja (ohjauskeskustelut, haastateltavien taustatiedot, omat päiväkirjamerkinnät). Pääasiallinen analyysimuoto on haastattelujen saattaminen tutkimusteemoja kuvaaviksi tyyppitarinoiksi, jotka kytkin teoreettiseen tietoon. Lopuksi kiteytin saadut tulokset käsitteelliseen muotoon.

\section{HENKILÖKOHTAISET NAISET}

Tutkimukseen osallistuneet naiset puhuivat sekä ohjauskeskusteluissa että haastatteluissa esimerkiksi työttömyydestään hyvin henkilökohtaisesti. Tunteet ja niiden ilmaiseminen olivat keskeisessä osassa. Sen sijaan miehet puhuivat niukkasanaisemmin ja kontrolloivat tunteitaan naisia tiukemmin. Esimerkiksi työttömyyden vaikutuksesta parisuhteeseensa miehet puhuivat hyvin vähän. Miesten puhe oli myös naisia enemmän niin kutsuttua asiantuntijapuhetta. Miehet analysoivat omaa tilannettaan naisia yleisemmällä ja ei-henkilökohtaisella tasolla. Naisten puheessa kuuluivat niin ilon, surun ja pettymyksen kuin odotuksen ja innostuneisuuden tunteet.

Naiset myös hakivat ja kokivat saavansa ohjaussuhteessa (esimerkiksi liittyen työttömänä olemiseen) sellaista tunnetukea, jota he eivät saaneet parisuhteessaan. Naiset eivät pystyneet jakamaan työttömyyskokemuksiaan perheittensä kanssa, koska eivät saaneet miehiltään riittävästi tunnetukea työttömyytensä keskellä (Silvennoinen 2007, 96), kuten lainaus Teijan tarinasta osoittaa:

Teija on kokenut työttömänä olemisen hyvin vaikeaksi ja raskaaksi. Hän on kokenut jäävänsä hyvin yksin työttömyytensä kanssa varsinkin viimeisten vuosien aikana. Teijan mies työskentelee viikot toisella paikkakunnalla ja aikuistuvat lapset ovat pian muuttamassa pois kotoa. Aviomies ei ymmärrä ja usko, että töitä ei ole helppo saada. Teijan tilannetta pahentaa se, ettei hän saa työmarkkinatukea, koska aviomiehen tulot ovat niin suuret. Hän on siis taloudellisesti riippuvainen miehestään. 
Aviomies on patistanut Teijaa hakemaan töitä jopa muilta paikkakunnilta, koska töitä ei tunnu saavan kotikaupungista. Periaatteessa Teija olisikin valmis lähtemään töihin toiselle paikkakunnalle ja eroamaan. Teijan ollessa työtön parisuhde on toiminut paremmin silloin kun mies on ollut töissä toisella paikkakunnalla. Lapset ovat olleet se tekijä, joka on pitänyt yllä Teijan elämänhalua, vaikka välillä on tullut ajateltua itsemurhaakin.

Ohjauskeskustelut ja ohjaussuhde toimivat naisille kenttänä, jossa naiset kokivat tulleensa ymmärretyiksi ja kuulluiksi sellaisina kuin ovat. He pystyivät reflektoimaan tilannettaan ohjaavan kouluttajan kanssa. Ohjaussuhde sisältää elementtejä puhtaista suhteista. Anthony Giddensin mukaan tyypillisin puhdas suhde on parisuhde. Puhdas suhde rakentuu sille, mitä se antaa osapuolilleen (esimerkiksi rakkautta, turvallisuutta ja tukea). Puhtaan suhteen toimivuus perustuu osapuolten väliseen luottamukseen ja vuorovaikutukseen. Luottamus syntyy vuorovaikutuksessa ja toisen kiireettömässä kuuntelussa. (Giddens 1995, 1-5, 88-99, 185-187.) Luptonin (1998) mukaan naiset pystyvät tasavertaiseen ja vastavuoroiseen vuorovaikutukseen miehiä paremmin, minkä vuoksi puhtaat suhteet ovat naisille helpompia kuin miehille.

Ohjaavan koulutuksen aikana käydyissä ohjauskeskusteluissa naiset pystyivät keskustelemaan tilanteestaan, itsestään ja tulevaisuudestaan sekä reflektoimaan elämäänsä ohjaavan kouluttajan kanssa tavalla, johon he eivät esimerkiksi pystyneet omassa parisuhteessaan, kuten seuraava haastattelulainaus Riitan tarinasta kuvaa:

Piia: Olisitko sä toivonu sellaista enempi että, ohjaaja tai sanotaan, että niin kun mä sanoin, 'mee tonne'?

Riitta: Minulle se sopi hyvin. Se on vaikea sanoa, sopiiko se kaikille, mutta tuota sehän perustu siihen keskusteluun ja mitä sä olit saanut käsityksen minusta ja minusta, ja minä itse olen sitä mieltä, että jos haluaa tuommoisen [ohjaavan koulutuksen projektin] rakentaa sen ihmisen omien kykyjen, halujen ja kiinnostusten kohteiden tämmösten perusteella siitäkin huolimatta, ettei hän itse tiedä mikä olis semmonen harjoittelupaikka niin juuri tämmönen tuntemus, että kouluttaja tuntee hieman ja hahmottaa sitä ihmistä ja mitä tässä vois olla sellaisia... Sitten siltä pohjalta ehdottaa. Mä tykkään, mulla olis monta asiaa loksahtanut paremmin, jos joku muukin olis tehny niin kun sinä, että vähän niin kun työntänyt, että 'mene vaan, kyllä sinä siellä pärjäät'. En tiedä missä olisin tänä päivänä jos joku olis niin mulle ennenkin niin tehny. Mä arvostan sellasta.

Piia: Eli olisit tavallaan niin kun kaivannut tukea niissä päätöksissä?

Riitta: Sana tuki on varmaan se oikee sana. Et siinä, se on ihan sama asia kun tuota mä rupesin taisteleen sitä [sana poistettu], niin mä olisin toivonut, että kun mä olin tukenu tavattomasti mun expuolisoo hänen urallaan. Ja hän kyllä anto siitä positiivista palautettakin... niin tuota kun hänen olis pitäny tehdä se minulle niin hänellä ei ollut haluja, kykyjä eikä resursseja. Ja sen kyllä koin hirveen raskaana. Mikään ei ole niin tärkeää kuin läheisen ihmisen tämmönen [tuki] ... jotenkin sellanen että...

Ohjaava kouluttaja toimii ohjattavalleen refleksiivisenä toisena. Refleksiivisen toisen käsite perustuu käsitykselle, jonka mukaan ihminen ei voi ymmärtää itseään ilman vuorovaikutusta toisen kanssa. Minuus ja identiteetti löytyvät ainoastaan autenttisissa suhteissa toisiin. Yksilö voi ymmärtää itseään ja identiteettiään toisen/toisten kautta, refleksiivisessä suhteessa. Itsereflektio mahdollistuu refleksiivisessä suhteessa toiseen. (Silvennoinen 2007, 56.) Käymissäni ohjauskeskusteluissa nimenomaan naiset pystyivät reflektoimaan identiteettiään ja tulevaisuuttaan ohjaavan kouluttajan kanssa. Tätä kuvaa esimerkiksi katkelma tulevaisuutensa suhteen varovaisen Riitan haastattelusta:

"Olettaisin, että minä olen opiskelemassa, mutta en oikeastaan enää tee... tämmösiä niin ku viimesen päälle. Nyt on monta kertaa elämässä sattunut että, että elämässä kaikki. Se on niin kuin korttitalo, joka hajoaa yhtäkkiä. Mä en niinku hirveesti enää rakenna tällaisia valmiita suunnitelmia että, että... mä otan kaiken irti tästä työssäolojaksosta, sen jäl- 
keen mä hakeudun koulutukseen ... mä katon vaan miten tää menee".

\section{ITSELLISET MIEHET}

Naiset ovat perinteisesti vastanneet perheen tunnetuesta esimerkiksi hoivan ja huolenpidon muodossa, mikä näkyy myös siinä, etteivät haastattelemani miehet kyenneet reflektiivisyyteen naisten tavoin. Naiset ovat siis vanhastaan tuottaneet ja ylläpitäneet hoivaa ja miehet ottaneet sitä vastaan (Ahlqvist 1996, 130-145). Miehet eivät siis naisten tavoin ehkä tarvinneet reflektoivia keskusteluja ohjaavan kouluttajan kanssa, koska he kävivät niitä mahdollisesti omien puolisoidensa kanssa, mihin katkelma Jounin tarinasta viittaa:

"Parisuhteeseen ja perhe-elämään työttömyys on vaikuttanut siten, että parisuhteessa on ollut kireitä jaksoja aina silloin, kun työpaikkahakemukset eivät ole tuottaneet tulosta ja optimismi työllistymisestä on kariutunut. Vaimo on kuitenkin ollut Jounille suurena tukena ellei avovaimoa olisi niin Jouni olisi mielestään täysin tuuliajoilla. Hän ei edes uskalla kuvitella, minkälaista olisi olla työtön sinkkumies."

Tätä olettamusta tukee myös tutkimukseni havainto, että työttömät naiset pystyivät toimimaan työssäkäyville miehilleen tunnetukena ja hoivan tuottajina sekä näkemään heidät moniulotteisemmin kuin mitä aviomiehet näkivät työttömät vaimonsa (Silvennoinen 2007, 89). Kari Vähätalon (1998) mukaan keskiluokkaisia arvoja toteuttava naisvaltainen auttamiskulttuuri on matalassa sosioekonomisessa asemassa oleville miehille outo, ja he kokevat sen keskustelukulttuurin ja toimintatavat itselleen vieraaksi, mitä seuraava haastattelulainauskin kuvaa:
Piia: Sanoit että et kaikille puhu?

Matti: Niin ... vaikee tohon on vastata, mutta tuota tietennii että kysymyksetkin onsemmosia, että niihin nyt viittii vastata ... vastata tuolleen, ettei nyt mene ihan tuota... liian, liian tuota syvällisiä eikä semmosia, että tuota ... jokuhan se on joka ihmisellä joku raja, johon se vastaa.

Vähätalon $(1998,109)$ tapaan onkin syytä kysyä, onko asiakkaan kannalta väärään sukupuoleen, väärään luokkaan ja väärään perheasemaan kuuluvan tai samastuvan ammattiauttajan mahdollista riittävästi ymmärtää saati auttaa työtöntä.

Miehet tulkitsivat ja arvioivat ohjauskeskusteluja lähinnä konkreettisen hyödyn perusteella. Heille ohjauskeskustelun funktio kiteytyi tavalla tai toisella työllistymiseen. Miehet tulkitsivat projektissa syntyneet suunnitelmat omaksi ansiokseen. Heidän mielestään ohjauksella ei ollut suurta osuutta asiaan. Miehet pitivät esimerkiksi työllistymistään omana ansionaan tai antoivat siitä kunnian omalle sosiaaliselle verkostolleen. Kyse on vahvasta oman kunnian ylläpitämisen kulttuurista. Suomalaisessa mielenmaisemassa menestyminen työssä ja elämässä yleensä on itsestä kiinni (vrt. Kortteinen 1992).

\section{SUKUPUOLEN MERKITYS OHJAUKSESSA}

Tutkimuksessani keskustelutilanteissa vaikuttivat pitkälti perinteiset sukupuoliroolit. Miehet eivät saaneet ohjauskeskusteluissa kanssani kokemusta vertaisuudesta, mikä osaltaan selittänee heidän vähäpuheisuuttaan, tunnepuheen välttämistä ja asiantuntijapuheen käyttöä. Naisten kanssa taas syntyi kokemus vertaisuudesta, refleksiivisestä toiseudesta. Esimerkiksi Teijan tarinassa korostuu ohjaajan merkitys sukupuolensa edustajana. Teija pystyi puhumaan elämästään vain naisen kanssa (Silvennoinen 2007, 86). 
Päivi-Katriina Juutilaisen mukaan sukupuolitietoisuus ja -herkkyys ohjaustyössä rakentuvat sille, että ohjaaja tunnistaa kontekstit, joissa sukupuolta tuotetaan. Tällaisia ovat esimerkiksi erilaiset rooliodotukset sekä vuorovaikutuksen ja toiminnan muodot. Ohjattavan sukupuoli vaikuttaa ohjauskeskustelun sisällölliseen kulkuun, ja on ohjaustilanteita, joissa sekä ohjaaja että ohjattavat kokevat itsensä sukupuolensa edustajiksi. Tällaisissa "sukupuolisen vertaisuuden" tilanteissa, joissa esimerkiksi "ollaan naisia molemmat ja ymmärretään nämä asiat samalla tavalla", syntyy kokemus eräänlaisesta "naistietoisuudesta”. Nämä vertaisuuden ja naistietoisuuden kokemukset muistuttavat feministisen ohjauksen ideaa, jossa ohjaajan ja asiakkaan tasaveroisuus perustuu juuri sille, että osapuolet ovat samaa sukupuolelta. (Juutilainen 2003, 185-186.)

Juutilaisen mukaan sukupuolisensitiivisellä ohjaajalla on narratiivista, sosiologista ja kielikulttuurista kompetenssia. Narratiivinen kompetenssi on kykyä kuunnella opiskelijan tarinaa ja astua tuon tarinan avulla opiskelijan maailmaan. Sosiologinen kompetenssi on tietoisuutta niistä biologisista, psykologisista ja sosiaalisista tekijöistä, jotka vaikuttavat naisten ja miesten asemaan yhteiskunnassa ja erilaisissa sosiaalisissa yhteyksissä. Sosiologinen kompetenssi merkitsee myös kykyä näiden tekijöiden eksplisiittiseen tarkasteluun ohjauksessa. Kielikulttuurinen kompetenssi on ohjaajan kykyä tunnistaa työssään sukupuoleen liittyviä kielellisiä elementtejä ja käyttää ymmärtävää ja moninaisuutta arvostavaa kieltä. Ohjaajalta vaaditaan myös kykyä naisten ja miesten ohjaukseen liittyvien uskomusten ja olettamusten kriittiseen arviointiin sekä omien tulkintojen kyseenalaistamiseen. Sukupuolisensitiivinen ohjaaja osaa analysoida oman henkilökohtaisen toimintansa vaikutusta ohjausprosessissa. (Juutilainen 2003, 206-208.)

Kaj Ilmosen mukaan asiakassuhteessa asiakkaat käyttäytyvät tunnepitoisemmin silloin, kun asiantuntijana on nainen. He purkavat kielteiset tunteensa ja pettymyksensä herkemmin naisiin kuin miehiin. Samoin asiakkaat liittävät myönteiset tunteet naisten olemukseen. Asiakkaat myös odottavat ja sallivat naisasiantuntijalle tunnepitoisemman käyttäytymisen kuin miesasiantuntijalle. Siinä missä naisille sallitaan tunneilmaisut osana asiantuntijatyöskentelyä, miesten odotetaan hallitsevan tunneilmaisuaan piilottamalla tunteensa. (Ilmonen 1999, 318.) Sari Näreen (1999, 263-299) mukaan tunnesäännöillä on taipumusta rakentua sukupuolispesifisti: samalla kun hegemoninen maskuliniteetti edellyttää tunteista etääntymistä, feminiinisyysdiskurssi kannattelee tunteiden ilmaisua.

\section{SUUREN MURROKSEN SUKUPOLVI JA ELINIKÄINEN OPPIMINEN}

Parisuhteessa osapuolet voivat elää hyvin erilaisessa yksilöllistymiskehityksen vaiheessa. Tutkimukseni miehet ovat kiinnittyneet modernin yhteiskunnan identiteetin ja roolien määreisiin. Miehille työ on keskeinen identiteetin määrittäjä. Miehelle perhe ja vaimo ovat tunnetuen ja hoivan tuottajia. Sen sijaan nainen voi elää jo yksilöllistymiskehityksen seuraavaa vaihetta, jossa tyydytystä ei tuokaan enää roolien mukainen "työliitto" vaan "tunneliitto" ja henkilökohtaisten toiveiden täyttyminen. Tutkimukseni naiset ovat jääneet yllättävän yksin työttömyytensä kanssa, eivätkä he koe saavansa parisuhteessaan tukea mieheltään vaan joutuvat kokemaan työttömyyden vailla lähisuhteiden ymmärrystä ja tukea. (BeckGernsheim 2002, 54-84; Silvennoinen 2007, 89.) Nämä asiat vaikuttavat siihen, minkälaisia toiveita ja tavoitteita miehet ja naiset asettavat ohjauskeskusteluille ja kuinka he keskusteluissa toimivat.

Nykyinen jälkimoderni työn maailma on sosiaalisempi ja kommunikatiivisempi kuin aiempi, moderni työn maailma (Julkunen 2003, 45-46). Työorganisaatiot ovat alkaneet muuttua miesten taitoihin perustuvista organisaatioista kohti naisten taitoja hyödyntäviä organisaatioita. Tekniikka, perinteinen johtaminen ja byrokraattinen kieli ovat vaihtuneet kuunteluun, kommunikointiin, improvisointiin ja sosiaalisiin taitoihin. (Häyrynen 1994, 190.) Työelämä on yksilöllistynyt ja tullut refleksiivisemmäksi. Tämä muutos ei kuitenkaan ole tavoittanut käytännössä kaikkia ihmisiä eikä maantieteellisesti kaikkia alueita. Muutos ei myöskään ole kaikille yhtä helppoa. Mitä vanhemmasta ikäluokasta on kysymys, sitä vaikeampaa on olla yksilöllisesti reflektiivinen ja ymmärtää työelämän 
refleksiivisyyttä. Miehille reflektiivisten toimintatapojen omaksuminen on työläämpää kuin naisille.

Peter Alheitin (1994, 283-293) mukaan yhä useamman työelämässä olosta on tullut entistä katkonaisempaa, minkä vuoksi koulutuksen painoarvo yksilön elämässä lisääntyy, halusi hän sitä tai ei. Kun ihmisten elämässä on työelämänkulun rinnalle tullut koulutuselämänkulku, koulutussuunnittelussa tulisi paremmin ottaa huomioon yksilöiden sukupolvikokemukset ja sukupuolten erot. Esimerkiksi suuren murroksen sukupolvelle (heti sodan jälkeen syntyneet ikäluokat) koulutuksella on ollut ensisijaisesti välineellistä arvoa. Heille nuoruudessa hankittu koulutus on mahdollistanut siirtymisen työelämään, ja keskeinen elämän sisältö on työ. (Kauppila 1996, 2002). Käsitys elinikäisestä koulutuksesta on tälle sukupolvelle varsin vieras.

Haastattelemani ikääntyvät pitkäaikaistyöttömät ovat lapsuudessaan ja nuoruudessaan sosiaalistuneet kollektiiviseen kasvatus- ja koulutuskulttuuriin. Heille koulutus näyttäytyy opettajakeskeisenä ja autoritaarisena toimintana, jossa opetus ja oppiminen tapahtuvat hierarkkisesti ylhäältä alaspäin sisältäen vain vähän kaksisuuntaista kommunikaatiota opettajan ja opetettavan välillä. Nykyinen individualistinen kasvatus- ja koulutuskulttuuri on refleksiivisempää ja tähtää elinikäisen oppimisen sisäistämiseen. Vaatimuksena on itseohjautuva ja reflektoiva oppija, jolla on hyvät vuorovaikutustaidot. (Hofstede 2001; Puurula 2002, 227-228; Vehviläinen 2001, 13.)

\section{LOPUKSI}

Tutkimuksessani pitkäaikaistyöttömät kokivat parhaimmaksi ohjauksen muodoksi toisilta työttömiltä saadun vertaistuen. Varsinkin miehet kokivat ryhmän keskinäisen vertaistuen tärkeäksi foorumiksi käsitellä työttömyyteen liittyviä tuntemuksia ja kokemuksia (Silvennoinen 2007, 55-57). Myös Heikki Pasasen (2007, 178, 192-201) tutkimuksessa kanssakäyminen toisten vastaavassa tilanteessa olevien kanssa ohjaavan koulutuksen erilaisissa käytännöissä koettiin merkityksellisimmäksi tekijäksi uuden ammatillisen identiteetin työstämisessä. Esimerkiksi toisten samanlaisessa tilanteessa olevien juttujen kuunteleminen ja omien kokemusten kertominen antavat mahdollisuuden vastavuoroisuuteen ja tasaarvoiseen kohtaamiseen ja keskinäiseen kunnioitukseen (Pasanen 1998; Sennett 2003), kuten seuraavat haastattelulainaukset osoittavat:

Matti: [Ohjaavan koulutuksen projekti] oli koulutuksena seuraava, ja tuota tietysti siinä oli sillon se että, että... tietysti lähti tavallaan ehtimään, kun siinä oli ikäjakauma annettu jo tuota pikkusen ylemmäks, niin rupes ehtimään jos löytyy samanikäsiä henkilöitä niin niin se kurssin, mikskä sitä nyt sanos, puheenaiheetkin on ehkä samalla tasolla kun pelekästään nuorten kanssa, monta kertaa kurssilla on enemmän, niin tuota voi tavallaan niillä kokemuksilla toisiaan auttaa.

Matti: Kyllä ja siinä [ryhmässä] tuota tavallaan sitten että... tuli, keskusteli henkilöiden kanssa jotka oli eri aloilla jossain, niin minkälaisia mahollisuuksia on ja mitä ne niin kun tarjoo. Siellä oli [ $x$-alan] ihmisiä, jotka halus sitten tuota sumtautua $[y]$-puolelle ja ja itte tuota harrastan kesällä tuota, [harrastusta] ... tavallaan jos jotakin pysty sitten tukemaan jotakin henkilöä sieltä, että 'mee ihmeessä jos kerta on semmonen' ja pyrki kertomaan, että miten minä tekisin jos minä oisin, että tuota että mitä minä ottasin huomioon, hän itte tekkee ratkasun siinä.

Huomionarvoista on myös se, että haastattelemani miehet eivät pystyneet keskustelemaan työttömyydestään omien ystäviensä kanssa. Miesten oma ystäväpiiri ei toiminut kenttänä, jossa olisi voinut käsitellä työttömyyttä. Miesten sosiaaliset verkostot aktivoituivat tilanteissa, joissa heillä oli oma palkkarahoitus mukanaan tullessaan töihin (esimerkiksi tukityöllistyminen projektissa). Työttömyys siis rapautti heidän sosiaalisia verkostojaan ja aiheutti yksinäisyyden ja häpeän kokemuksia, kuten seuraavat haastattelulainaukset valaisevat:

Matti: Ja sitten tuolla on mun koulukaverit, ja ne tietää, missä mä oon joskus ollu. Ja nyt... se on tuota niin, tää on ihme, monesti sanotaan, että ihminen on ihmiselle susi tuota niin... Siellä on niin mukava naureskella, että nyt sekin on tuota [työttömänä], ei mitään. Että tällaista.

Piia: Oliko sulla ennen sitä [ohjaavan koulutuksen 
projektia] niin kun mitään tällasta tekemistä muitten työttömien kanssa?

Matti: Ei.

Piia: Joo. Sä tavallaan niin kuin olit yksin työttömänä? Matti: Kyllä.

Piia: Oliko sulla ystäväpiirissä työttömiä?

Matti: Oli jotain.

Piia: Mutta heidän kanssaan et sitten?

Matti: Ei, ei ollenkaan, musta tuntuu että heillä oli samanlainen ongelma.

Piia: Joo, koetko sää että, tai onko sulla semmonen tunne että työttömät häpeää sitä työttömyyttään jopa niin paljon, että ne ei haluakkaan olla yhdessä, että mieluummin ollaan sitten vähän piilossa?

Matti: Määluulen, että se on hyvin yleistä.

Piia: Mistä se sun mielestä johtuu?

Matti: Kyllä se ehkä sillain, tavallaan itsetunto romahtaa niin kun alenee ja tuntee olevansa erilainen. Toiset puhhuu työstä ja itse ei voi keskustella siitä asiasta...

Piia: Ollenkaan?

Matti: Niin.

Ehkä tämän vuoksi työttömät miehet kokivat hyväksi sen, että ohjaavan koulutuksen projektissa he pystyivät keskustelemaan toisten samanlaisessa tilanteessa olevien kanssa ja saamaan tukea toisiltaan (Silvennoinen 2007, 57).

Sen sijaan naiset hyötyivät miehiä enemmän kahdenkeskisistä keskusteluista ohjaavan kouluttajan kanssa. Näissä keskusteluissa he puhuivat asioista, jotka liittyivät heidän yksityiselämäänsä (esimerkiksi parisuhde, lapset, äidin rooli) ja työttömyyteensä, kuten haastattelulainaus Riitan tarinasta osoittaa:

"Toisaalta kyllä mä tiesin että mä oon aika hyvä lastenkasvattaja ja tota tein kotonaolopäivästäkin työpäivän. Mutta tuota kyllähän se ... arvottomuuden tunnetta... se peilautuu hyvin paljon siinä parisuhteessakin myöskin elikkä kun hän [aviomies] ei voi esitellä vaimoaan, varsinkin kun hän on karriääri-ihminen itse niin ... vaimo ei tee mitään. Niin hienosti kun kaikki sanoo, että'onhan se hyvä olla hoitamassa lapsia kotona', mutta todellisuudessa maailma on niin raadollinen, että semmosella ihmisellä ei ole mitään arvoa, ja tästä mä en tingi tippaakaan. Mä oon kokenu sen niin... se ei ole pelkästään sisäänrakennettu asia vaan mä oon nähny se ja kokenu sen."

Tutkimukseni mukaan naiset ja miehet hyötyvät ohjauskeskusteluista sukupuolisosialisaationsa mukaisella tavalla: naiset kahdenkeskisistä keskusteluista ja miehet ryhmäkeskusteluista. Tästä syystä miehille tulisi lisätä ryhmäohjausta, joka antaa heille mahdollisuuden sosiaalisten verkostojen luomiseen ja hyödyntämiseen. Ikääntyvät naiset tarvitsevat puolestaan miehiä enemmän kahdenkeskisiä ohjauskeskusteluja ohjaajan kanssa. Miesten ohjaus tulisi myös olla konkreettisiin, työllistymistä edistäviin asioihin keskittyvää ohjausta siinä missä naiset tarvitsevat tunnetukea ja ohjaajan toimimista refleksiivisenä toisena. Sen sijaan ohjaajan sukupuolella ei tutkimuksessani ollut ratkaisevaa merkitystä ohjaus- ja keskustelutilanteiden kulkuun. Tutkimukseni miehet ja naiset käyttäytyivät pitkälti sukupolvelleen ominaisten sukupuoliroolien mukaisesti.

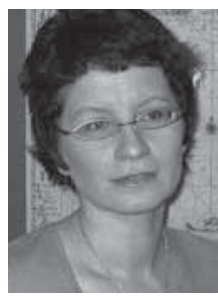

Piia Silvennoinen

YTT/PhD

Yliopettaja/Principal Lecturer

Laurea-ammattikorkeakoulu

\section{LÄHTEET}

Ahlqvist, K. (1996). Työ, työttömyys ja valinnanvapaudet. Teoksessa Ahlqvist, K. \& \& Ahola, A. (toim.) Elämän riskit ja valinnat - hyvinvointia lama-Suomessa. Helsinki: Edita, 129-148.

Alheit, P. (1994). The 'biographical question' as a challenge to adult education. International Review of Education 40 (3-5), 283-298.

Beck-Gernsheim. E. (2002). From 'living for others' to 'a life of one's own'. Teoksessa U. Beck \& E. BeckGernsheim. Individualization. London: SAGE, 54-84.

Giddens, A. (1995). Modernity and self-identity. Self and society in the late modern age. Cornwall: Polity Press. 
Heinämaa, S. (1996). Ele, tyyli ja sukupuoli. MerleauPontyn ja Beauvoirin ruumiinfenomenologia ja sen merkitys sukupuolikysymykselle. Helsinki: Gaudeamus.

Hofstede, G. (2001). Culture's consequences. Comparing values, institutions and organisations across nations. 2. painos. London: SAGE.

Häyrynen, Y-P. (1994). Henkiset kyvyt, itsemäärääminen ja organisaatiomuutos. Teoksessa Kuusinen, J. \& Heikkinen, E. \& Huuhtanen, P. \& Ilmarinen, J. \& Kirjonen, J. \& Ruoppila, I. \& Vaherva, T. \& Mustapää, O. \& Rautoja, S. (toim.) Ikääntyminen ja työ. Helsinki: WSOY/Työterveyslaitos, 185-195.

Hyvärinen, M. \& Peltonen, E. \& Vilkko, A. (1998). Johdanto. Teoksessa Hyvärinen, M. \& Peltonen, E. \& Vilkko, A. (toim.) Liikkuvat erot. Sukupuoli elämäkertatutkimuksessa. Tampere: Vastapaino, $7-25$.

Ilmonen, K. (1999). Työelämä ja tunteet. Teoksessa Näre, S. (toim.) Tunteiden sosiologiaa II. Historiaa ja säätelyä. Helsinki: SKS, 299-324.

Julkunen, R. (2003). Kuusikymmentä ja työssä. Jyväskylä: SoPhi.Juutilainen, P-K. (2003). Elämään vai sukupuoleen ohjausta? Tutkimus opintoohjauskeskustelun rakentumisesta prosessina. Joensuun yliopisto. Kasvatustieteen julkaisuja n:0 92.

Kauppila, J. (1996). Koulutus elämänkulun rakentajana. Teoksessa Antikainen, A. \& Huotelin, H. (toim.) Oppiminen ja elämänhistoria. Aikuiskasvatuksen 37. vuosikirja. Helsinki: Aikuiskasvatuksen Tutkimusseura ja Kansanvalistusseura, 45-108.

Kauppila, J.( 2002). Sukupolvet, koulutus ja oppiminen. Tulkintoja koulutuksen merkityksestä elämänkulun rakentajana. Joensuun yliopisto. Kasvatustieteellisiä julkaisuja N:o 78.

Kortteinen, M. (1992). Kunnian kenttä. Suomalainen palkkatyö kulttuurisena muotona. Hämeenlinna: Hanki ja jää.

Liljander, J-P. (1999). Pierre Bourdieu. Valikoiva erottautuminen koulutuksessa. Teoksessa Aittola, T. (toim.) Kasvatussosiologian teoreetikoita. Helsinki: Gaudeamus, 105-128.

Lupton, D. (1998). The emotional Self - a sociocultural exploration. London: SAGE.
Näre, S. (1999). Sukupuolten tunnekulttuuri ja julkisuuden intimisoituminen. Teoksessa Näre, S. (toim.) Tunteiden sosiologiaa I. Elämyksiä ja läheisyyttä. Helsinki: SKS, 263-299.

Pasanen, H. (1998). Refleksiivisen itseohjautuvuuskäsitteen hahmotusta. Teoksessa Manninen, J. (toim.) Aikuiskoulutus modernin murroksessa. Näkökulmia työllistymistä edistävän koulutuksen ja ohjauksen merkityksiin ja vaikuttavuuteen. Helsingin yliopiston kasvatustieteen laitoksen julkaisuja 158, 11-59.

Pasanen, H. (2007). Ohjaava koulutus merkitysten kenttänä - identiteetin muutos ja moniulotteisuus ammatillisessa rehabilitaatiossa. Joensuun yliopisto. Kasvatustieteellisiä julkaisuja N:0 121.

Puurula, A. (2002). Aikuiskasvattajan roolimuutos kollektiivisissa ja individualistisissa kulttuureissa. Teoksessa Sallila, P. \& Malinen, A. (toim.) Opettajuus muutoksessa. Aikuiskasvatuksen 43. vuosikirja. Helsinki: Kansanvalistusseura, 225-238.

Ronkainen, S. (1999). Ajan ja paikan merkitsemät. Subjektiviteetti, tieto ja toimijuus. Helsinki: Gaudeamus.

Savioja, H. \& Karisto, A. \& Rahkonen, 0. j\& Hellsten, K. (2000). Suurten ikäluokkien elämänkulku. Teoksessa Heikkinen, E. \& Tuomi, J. (toim.) Suomalainen elämänkulku. Helsinki: Tammi, 58-73.

Sennett, R. (2003). Respect in a world of inequality. New York \& London: W.W. Norton \& Company.

Silvennoinen, P. (2007). Ikä, identiteetti ja ohjaava koulutus. Ikääntyvät pitkäaikaistyöttömät oppimisyhteiskunnan haasteena. Jyväskylä: Jyväskylä Studies in Education. Psychology and Social Research 303.

Vehviläinen, S. (2001). Ohjaus vuorovaikutuksena. Helsinki: Gaudeamus.

Vähätalo, K. (1998). Työttömyys ja suomalainen yhteiskunta. Helsinki: Gaudeamus.

Artikkeli saapui toimitukseen 21.3.2011.

Se hyväksyttiin julkaistavaksi toimituskunnan kokouksessa 15.8.2011. 